Royal Ontario Museum

Life Sciences

Miscellaneous Publication

\title{
Methods for the \\ Collection, Preservation, and Study of Water Mites (Acari: Parasitengona)
}

David Barr

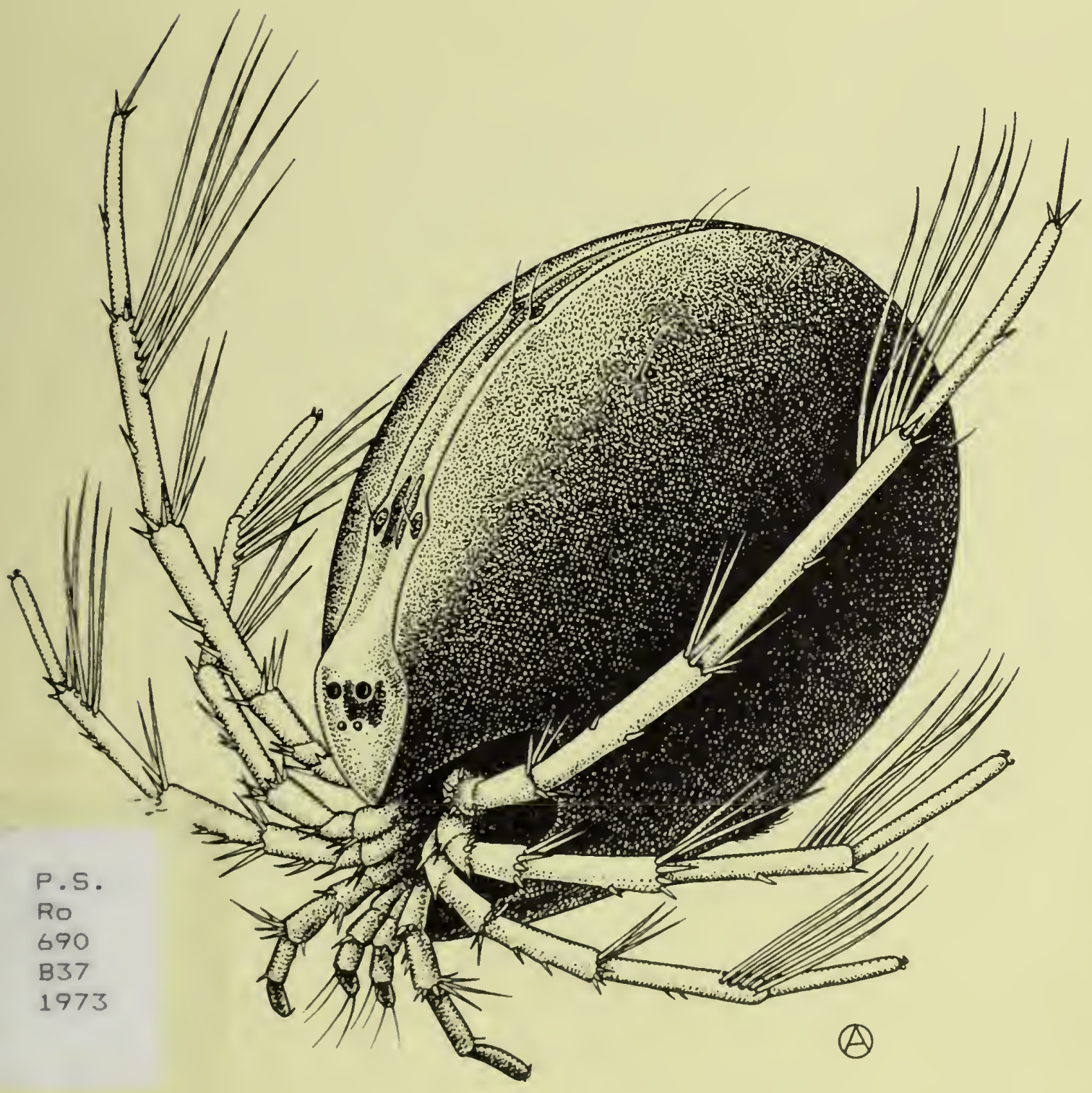


Digitized by the Internet Archive in 2012 with funding from Royal Ontario Museum 
I.IFE SCIENCES

MISCELLANEOUS PUBLICATIONS

ROYAL ONTARIO MUSEUM

DAVID BARR Methods for the

Collection, Preservation, and Study of Water Mites

(Acari: Parasitengona)

Publication date: 15 October 1973

ISBN 0-88854-148-1

Suggested citation: Life Sci. Misc. Publ., R. Ont. Mus. 


\section{PUBLICATIONS IN LIFE SCIENCES}

The Royal Ontario Museum publishes three series in the Life Sciences:

LIFE SCIENCES CONTRIBUTIONS, a numbered series of original scientific publications, including monographic works.

LIFE SCIENCES OCCASIONAL PAPERS, a numbered series of original scientific publications, primarily short and usually of taxonomic significance.

LifE SCIENCES Miscellaneous PUblications, an unnumbercd scries of publications of varied subject matter and format.

All manuscripts considered for publication are subject to the scrutiny and editorial policies of the Life Sciences Editorial Board, and to review by persons outside the Museum staff who are authorities in the particular field involved.

\section{LIFE SCIENCES EDITORIAL BOARD}

Chairman: R. L. PETERSON

Editor, J. R. TAMSITT

Associate Editor, D. BARR

Associate Editor, E. J. Crossman

DAVID BARR is Associate Curator in the Department of Entomology and Invertebrate Zoology, Royal Ontario Museum and Assistant Professor in the Department of Zoology, University of Toronto.

PRICE : $\$ 1.50$

(C)The Royal Ontario Muscum, 1973

100 Queen's Park, Toronto, Canada

PRINTED AT THE UNIVERSITY OF TORONTO PRESS

LIBRARY

ROYAL ONTARIO MUSEUM 


\section{Contents}

Abstract. 1

Résumé. 1

Introduction, ?

Collecting, 2

Lentic Habitats, 2

Lotic Habitats, 3

Water Margin Habitats, 6

Moss Habitats, 6

Phreaticolous Habitats, 7

Hosts, 7

Larvae and Eggs, 7

Preservation of Adults and Nymphs, 8

Larval Mites, 9

Rearing, 9

Harvesting and Preservation, 10

Practical Considerations, 12

Observation and Final Storage of Skeletal Preparations, 12

Exoskeleton of Adults and Nymphs, 12

Sorting and Clearing, 12

Dissection, 13

Classical Slide Mount, 13

Fluid Storage, 14

Temporary Mounts, 14

Semi-permanent Mounts, 15

Permanent Mounts, 16

Ejaculatory Complex, 16

Larvae, 17

Optical Sy'stems, 18

Studies on Internal Anatomy, 19

Scanning Electron Microscopy, 19

Applications, 19

Desiccation, 20

Mounting and Coating, 20

Limitations, 21

Illustrations, 21

Line Drawings, 21

Photomicrography, 23

Acknowledgments, 24

Appendix: Formulae for Reagents, 25

Literature Cited, 26 



\title{
Methods for the Collection, Preservation, and Study of Water Mites \\ (Acari: Parasitengona)
}

\begin{abstract}
Methods required for the systematic study of water mites include new techniques that complement or replace some already in existence. Netting, trapping, and separation procedures are described for mites collected from Ientic, lotic, moss, water-film, and phreaticolous habitats. The most useful larval specimens are obtained by collecting gravid females and harvesting larvae hatched from eggs deposited in the laboratory.

Fluid storage is preferable for most specimens. A versatile method of examining exoskeletal morphology is to observe temporary slide mounts with light microscopy (bright-field, interference contrast, or phase contrast). Scanning electron microscopy of desiceated mites enhanees the study of surface finc-structure but does not replace conventional techniques of illustration (line drawings, photomicrography).
\end{abstract}

\section{Résumé}

Les méthodes requises pour I'étude systématique des mites aquatiques comprennent des techniques nouvelles qui complémentent ou remplacent quelques-unes de celles en existence maintenant. Des procédés de prendre en filct, d'attraper et de séparer sont décrits pour des mites recucillies des habitats lentiques, lotiques, phréatiques, de la mousse, et de la filme d'eau. Les spécimens des larves les plus utiles sont obtenus en receuillant des femelles eneeintes et en récoltant des larves éclosés des oeufs deposés au laboratoire.

Conservation en fluide est préférable pour la plupart des spécimens. Une méthode versatile d'examination de la morphologic exosquelcttique e'est l'observation par microscopic optique (illumination ordinaire, interférence contrastéc, ou phase contrastée) des montures temporaires en lamelle. La microscopic électronique exploratrice des mites desséchées augmente l'étude de la structurc fine de la surface, mais clle ne remplace pas les techniques conventionelles d'illustration (dessins en ligne, photomicrographie). 


\section{Introduction}

The aquatic families of the suborder Parasitengona are among the most studied taxa of the Acari. Ncverthcless, methods of collecting, preparing, and studying these creatures are not standardized, and many useful techniques arc either unpublished or scattered throughout acarological literature. I therefore summarize methods found to be useful for systematic research with specimens of water mites. The account is directed primarily to those beginning in the field but also to established workers wishing to explore unfamiliar teehniques. Because new methods are continually developed while old oncs are being modified and improved, only an interim report is possible.

The treatment is not always comparative, for less satisfactory alternatives are not discussed unless well entrenched in the literature. Nor is the survey completc, for important areas of research (e.g., karyology, transmission electron microscopy, chromatography, electrophoresis) with which I have minimal experience are omitted. But procedures fundamental to systematic, evolutionary, ecologieal, life history, and zoogeographic studies are covered.

Viets (1936) first compiled methods for water mite study in his general treatment of the German species. There was no other comprehensive survey until those of Cook and Mitchell (Cook and Mitchell, 1952; Mitchell and Cook, 1952) appeared. Other sources of information have been limited in scope. Several authors of general works have described techniques of specific interest to water mite workers (Pennak, 1953; Newell, 1959) or for other mites (Grandjean, 1935, 1949; Newell, 1947; Baker and Wharton, 1952; Krantz, 1970) that can be used for water mites, either directly or with modification. Evans et al. (1961) published perhaps the most complete description of gencral acarological techniques available in English.

\section{Collecting}

Most collecting proeedures described here involve gathering a portion of the habitat (vegetation, gravel, soil, detritus) and separating the mites from it. Although separation is usually performed in the field, material may be returned to the laboratory for this operation when convenient.

In collecting adult mites, it is worthwhile to strive for quantity. Series of 50-100 specimens of a single species per locality are not too cxtensive. Not only arc large numbers valuable in taxonomic research but are mandatory if mites arc to be used as well for sectioning, rearing, karyology, or scanning electron mieroscope (SEM) observation.

\section{LENTIC HABITATS}

Many larger species of water mites occur in standing bodies of surface water - ponds, lakes, and ditehes. These mites arc easy to collect and have received attention from students of the group for more than a century. Cook and Mitchell (1952) deseribed the dip-nctting technique that is most useful for collccting in this habitat, a mcthod particularly cffective because most of the mites of standing waters swim wcll. They readily lcave nettcd vegetation and detritus floated in a whitc enamel tray and are easily picked up with a dropping pipcttc and placed in the collecting container. 
A useful collecting accessory is a polyethylene dropping pipette with a tapered tip. If progressively larger sections of the soft, plastic tip are sliced off, the corresponding intake bore of the pipette is increased. With several of these pipettes, one can efficiently handle mites of widely different sizes.

Periodically the amount of water in the collecting vial is reduced with the pipette (tip held against the bottom to exclude mites) so that additional specimens can be added. The collection is then transported to the laboratory for biological work; or all water may be pipetted off and the preservative added in the field.

Deep-water $(>2 \mathrm{~m}$ ), benthic mites (e.g.. Huitfeldtia) are not accessible with standard techniques and are usually collected using a dredge sampler, a slow process yielding small numbers of specimens. Pieczynski (1962, 1965 ) employed underwater traps for sampling mites of standing-water habitats.

Certain lentic habitats, notably temporary pools and many boggy situations, contain at the same time large amounts of dead vegetation and detritus and numerous species of mites that either do not swim readily or that crawl on the bottom. As Cook and Mitchell (1952) pointed out, crawling species are difficult to separate by the technique of dip net and enamel tray. Generally, too much detritus is taken in the net. Most specimens do not come out but must be sought by turning over every piece of plant material in the tray. Collection, even of swimming species, is hampered by excess debris. The suggestion of picking over vegetation in the pond (Cook and Mitchell, 1952 ) is valuable, and in some situations a more specialized technique, developed by Ian M. Smith (pers. comm.) to collect species that do not swim readily, may be helpful. His method involves holding an enamel tray submerged 3-15 $\mathrm{cm}$ beneath the surface of the water to form a clear, white background. Working it gently through and under bottom detritus, one can see nites swimming or occasionally crawling across the white background and pick them up, one by one, with a pipette.

\section{LOTIC HABITATS}

Numerous mite species also inhabit running water. Perhaps the method proved to be most useful in a variety of lotic situations is the technique (Cook and Mitchell, 1952) of washing submerged vegetation (panning). Masses of aquatic or submerged terrestrial vegetation are collected by hand and transferred to a white enamel tray filled with $3-5 \mathrm{~cm}$ of clear water. Vegetation is floated in the tray, taking care that not too much is added to a given tray. Within 5-30 minutes, depending on the initial temperature of the stream water, mites leave the vegetation to swim in the open water or crawl across the tray bottom. The method is slow, particularly when the stream temperature is low $\left(<15^{\circ} \mathrm{C}\right)$ and the appearance of mites delayed. Thus, efficiency is increased by running two or more trays simultaneously. The coarse screen mentioned by Cook and Mitchell (1952) is not necessary and is restrictive when collecting specimens continuously as they appear. It is necessary, however, to move the clumps of vegetation occasionally to discover mites on the tray beneath. 
With this technique are taken many species occurring in various microhabitats in the stream other than the truly phreaticolous species that characteristically inhabit gravel several inches below the stream bed (see p. 00). The relative numbers of species found in vegetation differ from those at other locations in the stream, but the species diversity of vegetation collections is sufficiently great to justify this method as the first choice in a new locality when time is limited.

The type of vegetation chosen for panning will vary with stream type. Fine-structured plants are more productive than simple, large plants of gross structure; i.c., aquatic mosses (Musci) are usually superior to Nasturtium spp. In turn, finc-structured mosses are usually more productive than species with larger leaves. Mites are also found in clumps and mats of algae, particularly those taken from riffle areas of a stream. If truly aquatic vegetation is sparse, submerged terrestrial vegetation will often be productive; e.g., grasses (Graminae) hanging over the bank, roots of grasses and other angiosperms along the bank and occasionally in the centre of the stream, or islets of grass or other terrestrial vegetation growing on a submerged log or other stable location in the watercourse. The technique of panning submerged vegetation will yield at least a few mites from almost any running water.

A useful method to separate crawling or weakly-swimming mites from vegetation in rheocrene springs and seepage areas has been used extensively by David R. Cook (described in litt.). When examined directly in a pan, this material often contains so much mud and suspended organic matter that organisms are difficult to see. Instead, handfuls of vegetation, including moss, matted roots, and leaves, are placed in a pail or large, wide-mouth jar, and only enough water is added to cover the plant material. Pieces of cheesecloth cut into $10 \times 20 \mathrm{~cm}$ strips are crisscrossed on top of the material so that at least two or three layers are placed everywhere. If the pail is then not disturbed for a few hours, most mites move toward the surface (perhaps in response to decreasing oxygen levels in the vegetation) into the cheesecloth, which can later be removed strip by strip and examined in a tray of clear watcr. Mites clinging to the cheesecloth are easily seen and collected.

A stream bed with a depth of 5-30 cm of loosely consolidated gravel often yields many mites, most of which live in the top $5-10 \mathrm{~cm}$ of gravel or underneath stones on the stream bed. A method developed by the author has proved to be valuable in a variety of gravel-bed stream habitats. A coneshaped (base:height 1:3) net of $125 \mu \mathrm{m}$ plankton netting is held by hand in the stream, with the mouth opening upstream. The opening is covered with coarse aluminum window screening (seven wires $/ \mathrm{cm}$ ) to exclude stones and large pieces of debris. The collcctor stands upstream from the net and, with his boots, vigorously disturbs the substrate to a depth of 15-20 $\mathrm{cm}$. Still holding the net under water, he slowly collects upstream for a distance of 3-4 m. The net is then withdrawn from the water and is held up so that sediment drains to the bottom. Additional water is splashed into the top of the net to wash down the sediment.

All sediment collected is then distributed evenly over the bottom of a white enamel tray containing $3-5 \mathrm{~cm}$ of clear water. Material collected, 
which is composed of fine gravel, silt, and other detritus, should form a layer no more than about $3 \mathrm{~mm}$ deep when spread over the pan. Mites begin to leave the sediment as soon as it settles, climbing over the surface and burrowing through the material. Many species that live in this habitat are small but usually can be seen against the dark substrate because of the dorsal white or pale spot that marks the site of the excretory gland. Species lacking a visible excretory gland are often otherwise conspicuous because of coloration or movement. Many smaller mites (e.g., Aturus spp.) swim actively above the substrate and may even reach the surface of the water in the collecting tray. Detection of specimens is nonetheless a problem, and collecting under a heavy overcast or in rain is difficult.

The plankton-net technique is superior to the screening method ctescribed by Cook and Mitchell (1952), for many specimens pass through coarse insect screening without clinging to the wire. In a productive gravel-stream habitat, a comparative test of the two methods clearly demonstrated the superiority of the modified plankton net (Barr and C. A. Lanciani, unpubl. data). It offers probably the best way to obtain the large samples (up to several hundred specimens per net sample) required for diversified research needs. Even so, dip-netting should not be neglected in the stream habitat, especially in areas of marginal vegetation and silt deposits in slow water.

Most lotic species are relatively small and can be readily collected with a small, glass, dropping pipette (medicine dropper type). Because many stream mites are adapted to cling to smooth surfaces in a current (often with the aid of secreted mucilaginous substances), they easily become lodged in the pipette and may be difficult to extract. But individuals usually detach when water in the pipette is allowed to rest momentarily, and the mite again floats or swims. Then water in the pipette is rapidly expelled into the collecting vial.

Experience has shown that not all suitable-appearing streams have a rich gravel fauna. As many different collecting techniques should be tried at each locality as time permits. In many streams and rivers and along rocky, waveswept lakeshores, water mites occur on the underside of flattened rocks lying on the gravel-based substrate. By carefully cxamining the surface of the rock after removing it from the water, specimens can be detected and picked off, either with fine forceps or a sharpened toothpick as described by Cook and Mitchell (1952). Collecting by this method, however, is tedious. Crowell (1960) described a method of brushing the underside of the rocks into a pan of water and collecting the dislodged mites with a pipette. Specimens can also be obtained by merely placing the stone in a pan of still water and allowing mites to leave of their own accord. Most rheophilic mites begin to move when placed in still water, more actively as the temperature of the water increases and oxygen content drops.

Water mites are usually among the fauna captured by drift nets placed in running waters (e.g., see Clifford, 1972). Drift sampling may represent a means of obtaining data on the composition of a stream mite fauna but is unlikely to reveal diversity as well as several of the methods described above. 
The water-margin habitat supports several highly-specialized species (Mitchell, 1960), the most common being Tyrrellia spp. These mites, which live in a film of watcr less than the thickness of their own bodies, can be collected slowly and tediously by scanning a prospective habitat visually from a distance of $20-40 \mathrm{~cm}$. Specimens are rcmoved from the surface one at a time with a pair of fine forceps. Appropriate situations are beds of moss kept moist by spray from falls or rapids, moist banks of streams and lakes (particularly wet bits of wood), stretches of mud-bank, and the stem bases of semi-terrestrial vegetation near the water-line. The surface must glisten with a thin film of water to be suitable for mites. Many water-film species are bright red and easy to see against the background, but $T y$ rrellia spp. are occasionally dark and inconspicuous.

\section{MOSS HABITATS}

Clumps of moss (Musci) growing on stones or wood submerged in flowing water may harbour populations of unusual and often primitive genera of mitcs (e.g., Trichothyas, Panisus, or Hydrovolzia). Often the most productive moss samples grow at the air-watcr interface along banks or on projecting objects in the centre of the water where they are always abundantly saturated but never submerged. The same productive habitat may occur in wet areas created by springs or in the spray zone of rapids or waterfalls.

Spccies found in saturated moss are usually sessile and will not leave the vegetation even if the sample is submerged in still, shallow water indefinitely. Two methods can be used to extract them from the sample, one simpler and morc straightforward than the other. Although both techniques are equally effective, both are biased for certain taxa.

The first is a simple field expedient. A clump of moss is held in one hand and systematically picked apart, strand by strand, with a pair of iris forceps. Most species found in mosses are bright red or orange, are easily seen ncar the base of the stalks of moss, and can be removed with little difficulty using forccps. Eggs and imagochrysalids attached to leaves and branches of the moss can be removed only by breaking off a small section of the plant and placing it in a collecting vial. Adding vegctation also gives living mites in the vial additional surface arca for climbing, thus reducing the chance of encounter and consequently of damage by predation. With the hand-picking technique, large numbers of adult and immature mites, coloured red, orange, yellow, pink or even brown, are detected. Dark coloured specimens, such as some Laversia spp., however, could be missed in this type of scanning.

A second tcchnique is morc likely to yicld cryptically colourcd mites (I. M. Smith, pers. comm.). Moss is rapidly shredded, strand by strand, into a tray of still water. When the entire sample has becn immersed, the watcr is stirred and vigorously swirled around the tray to allow all mites to become detached. Then loose moss is gathered, rinsed slightly as it is removed from the water, and set aside. When the water clcars, numcrous mites can be secn lying on or crawling through a layer of brown sediment that has settled on the bottom of the tray. Specimens can then be collected rapidly. Although dark-coloured mites will be frec and actively crawling, 
they still may be diffieult to see against the dark background of sediment. The method does not, however, facilitate the eollection of wholly sessile life history stages.

Both techniques were tried on moss samples from the same loeality, subsequently subjecting discarded moss to examination by the alternate technique. In each instanee a number of mites missed by the first method were taken by the second. At present, data are lacking to indicate the relative effieieney of the two techniques. Hand-pieking is simpler in the field, but both methods require good lighting for effective seanning.

\section{PHREATICOLOUS HABITATS}

The diverse mite fauna of interstitial (subterranean) waters can be collected by the method of Karaman-Chappuis (Motas, 1962). First, a hole deep enough to penetrate the water table is dug in the bank of a stream. The hole fills with water, which is scooped out and passed through plankton netting to concentrate specimens. Water removed from the hole is replaced by flow from ground water percolating through the sand or gravel interstices and carrying with it the fragile, colourless mites of the phreatic habitat. Speeimens are best removed from the accumulated debris under a dissecting microseope. Cook published on North American collections (e.g., 1963, 1968) taken in this manner and found poorly consolidated gravel bars along the banks or in the centre of streams to be particularly productive.

\section{HOSTS}

Studies of water mite life histories and host-parasite interactions demand considerable effort and ingenuity in collecting parasitized host inseets. From the host can be obtained larvae, larval sclerites and, often, associated nymphs. There is, of course, no general collecting technique. The host of the species of interest must be determined and then standard entomological techniques (Oldroyd, 1970) applied to collect that host. Although the incidence of parasitism is oceasionally high, especially with the aquatic Hemiptera, it is often less than $10 \%$ (e.g., Coleoptera; Lanciani, 1970).

Aquatic hosts are efficiently collected with the dip net and enamel tray described for collecting adult water mites. A useful accessory to remove fast-swimming Coleoptera and Hemiptera from the collecting tray is a small tea strainer. Once isolated in the strainer, the specimen may be knocked into a colleeting jar or removed with foreeps and preserved. Oldroyd (1970) deseribed an underwater light trap for capturing aquatic Hemiptera (also see Pieczynski, 1962). Aerial hosts may be netted on the wing or at rest by sweeping vegetation close to the banks of the body of water. They may also be taken with black (ultraviolet) light or in various types of emergenee cages.

Engorged larvae or nymphochrysalids removed from hosts may be satisfactory for identification but are usually too damaged or deformed to be valuable for taxonomic deseriptions.

\section{LARVAE AND EGGS}

Larvac are usually colleeted in the field only ineidentally and may be diseovered in collections of adults at the time of initial sorting. Larvae can 
occur in stream collections taken with a plankton nct, probably having been mistaken for adults of some small stream species, and collected with the pipette. Occasionally larvae occur in large numbers on the surface film of standing waters, where they may be collccted with any type of cloth net swept across the water with the lower edge just beneath the surface. The net must be everted into alcohol immediately upon removal from the water to kill the larvae and prevent them from swarming out.

When picking through moss samples, larvae will occasionally be noticed climbing over the vegetation. Single larvae may be picked up with the tip of a pair of fine forceps or a fine camel's hair brush dampened in $70 \%$ ethanol.

Eggs also are not commonly sought in the field but may be observed in numbers in pond and moss habitats. Egg masses should be taken with a bit of vegetation to the laboratory, isolated in a small container of water, and held until the time of hatching. Field-collected larvae and egg masses are less useful taxonomic material at prescnt, because in the absence of larval descriptions, only circumstantial cvidence is available for association with the adult form.

\section{Preservation of Adults and Nymphs}

For taxonomic purposes the best preservative for adult and nymphal water mites is modified Koenikc's solution (GAW; see Appendix) as recommended by Mitchell and Cook (1952), for specimens preserved in alcohol or formalin are more difficult to clear (see p. 12).

GAW-preserved specimens of most water mites are flexible, yet firm, and are easily cleared in acetic corrosive (André's fluid) or potassium hydroxide solution (Mitchell and Cook, 1952). The resulting preparations are strong and transparent. So robust are GAW-prescrved specimens that they are easily handled, and breakage of specimens caused by routine transfer or dissection is rare. Mites with large areas of wcak, membranous integument (c.g., large Eylais spp., Limnochares spp., and Wandesia spp.) become fragile in GAW, but at least the sclcrites arc casily clcared. In practice, adult mites are stored indefinitely in the original prescrvative until they arc clcared for detailed study.

When adult mites are prepared for the study of internal morphology, a histological fixative is recommended. Several standard reagents, for example Brasil's fluid (Mitchell, 1964), are satisfactory, especially for soft-bodied mites. Often, however, in the preparation of serial sections, hard sclerites of the body wall interfere with the cutting process. Adjacent areas of the section are often damaged, or the entire section may be destroyed. One solution involves embedding in a plastic medium (De Giusti and Ezman, 1955; Woodring and Cook, 1962).

To eliminate these disadvantages more simply, adult mites can he preserved with a fixative that hardens soft tissuc but does not unduly harden sclerotized structures. Such a fixative (modified Carnoy's), described by De Giusti and Ezman (1955), has proved to be satisfactory in preparing hard-bodied, sclerotized mites for sectioning. The fixative should be pre- 
pared freshly each time. After one week in the fixative, specimens ean be washed and stored in $70 \%$ isopropyl alcohol until ready for embedding.

\section{Larval Mites}

\section{REARING}

A prime requisite in eolleeting and preserving larval mites is that larvae be readily associated with adults of the correet speeies. An unambiguous association makes identification possible and permits further study of the biology of the speeies. The single most satisfactory method of obtaining larval material for study is to rear eggs laid in the laboratory by female mites.

Females, obtained in the field by any of the methods previously deseribed, are taken to the laboratory as rapidly as possible and isolated in small containers of water. Two-dran shell vials containing about $1 \mathrm{~cm}$ depth (i.e., $1 \mathrm{ml}$ ) of water proved satisfactory for most speeies reared in this laboratory. A short ( $1-2 \mathrm{~cm})$ strip of filter paper placed in the vial seems to stimulate oviposition in some species. Females are then held at room temperature (which in Toronto may rise to $30^{\circ} \mathrm{C}$ in summer) and observed every 3 days to determine if oviposition has oceurred or if water must be added to replace loss through evaporation. Whenever possible, the original water is from a elean lake or stream near the laboratory, but the level is maintained with glass-distilled water.

Some mites collected from temporary ponds shortly after the iee melts or from cold springs and streams may survive better if maintained at $5-15^{\circ} \mathrm{C}$. Cooling is oceasionally necessary to keep the female alive, although low temperatures also severely retard the rate of embryonic development.

Several systems of organizing females and reared larvae have been tried in this laboratory. The most convenient to date consists of holding isolated females in rearing vials in clear plastic boxes grouped by collection. A shallow box (approximately $55 \times 120 \mathrm{~mm}$ ) that holds 27 two-dram vials ean be placed easily under a disseeting microseope and seanned to eheek each specimen. Seanning should be done every 3 days, watching for either oviposition or death of the mite in the vial. If a mite dies, it is removed and preserved in GAW. If oviposition oceurs, the vial is separated with others containing eggs by a eardboard divider. The female is left with the eggs until they hateh or until she dies. If the female dies before the eggs hatch, she should be removed, preserved in GAW, and assigned a rearing number that is also given to the vial of unhatehed eggs. This number allows a female and the larvae reared from her eggs to be associated subsequently and also identifies individual rearings within monospecifie series from a given habitat.

Although only females have been discussed, an advantage of the system deseribed is that when space and equipment permit, entire colleetions of mites ean be set up without preliminary field sorting. They are scanned as before. Gravid females that oviposit are separated from non-ovipositing mites, and the rearing proeess is followed to completion. Non-gravid females. males, and nymphs, are simply preserved in GAW at the time of death and stored in a single vial kept for that eollection. The only additional proeessing required for non-reproduetive speeimens is the time spent seanning them. 
Vials in which oviposition has been observed should thereafter be cheeked more frequently. During embryonic development, partially-developed embryos can be harvested if required.

\section{HARVESTING AND PRESERVATION}

Larvae are harvested as soon as possible after hatching. Prasad and Cook (1972, p. 5) discussed techniques to extract eggs from the female prior to oviposition and to assist larvac to leave the egg membranes. Normally, larvae are removed from the rearing vials and preserved, and the female is preserved in GAW, both components of the collection receiving the same permanent rearing number.

When it is suspected that a femalc being held for oviposition will produee aerial larvae, rearing is probably best carried out in a stoppered vial (aquatie larvac are reared in open vials). Soon after hatching, acrial larvac may be crawling everywhere on the inside of the vial. To facilitate harvesting, $0.5 \mathrm{ml}$ of $70 \%$ ethanol is added to the vial, the stopper replaced, and the vial agitated thoroughly. Alcohol reduces the surface tension of the water, allowing the larvae to be wetted. When contents of the vial scttle, all larvac will probably be submerged and partially paralyzed by the alcohol, preventing them from passing through the surface film again. From this point aerial and aquatic larvae are treated alike.

Larvae, first drawn from the rearing vial into a Pasteur pipette with as little water as possible, are then pipetted into the depression of a white poreclain concavity plate. Pipettes should be rinsed frequently between transfers to avoid mixing larvae from different females. From the eoneavity plate, larvae are transferred singly (or two or three at once if possible) to a polyethylene microvial (Fig. 1A) filled to the brim with a solution of 1 part glyeerin in 9 parts $70 \%$ ethanol, a glyeerinc-based fluid with a surface tension sufficiently low to allow larvae to be submerged easily. Transfer is effected with a microloop construeted from a bent minuten pin (Fig. 18). Such a loop has proven useful for most operations involving the transfer of larvae or of disseeted adult structures.

Polyethylene microvials employed are sold by some entomologieal supply houses as "genitalia vials" and are also available from industrial suppliers (e.g., Caplug Division, Protective Closures Co., Inc., Buffalo, N.Y.) as "tubing caps." Transfer of larvac from water to preservative, perhaps the most time-consuming segment of the operation, provides for minimum dilution of the preservative and climinates any need to coneentrate specimens before final storage. Microvials are left unplugged overnight to allow aleohol and water to evaporate. The larvac remain in a small drop of glyeerin at the bottom of the microvial and so preserved can be stored indefinitely.

Long-term storage in glyecrin apparently has only a minimal effect on larval specimcns. Some internal maccration may occur, but further clearing is invariably required before mounting for observation with transmitted light. Legs, setac, and integument remain reasonably supple.

Microvials are ultimately stoppered with a tiny cork stopper (no. 000, $4 \mathrm{X}$ grade) to keep out dust and other foreign material. No particular seal is 

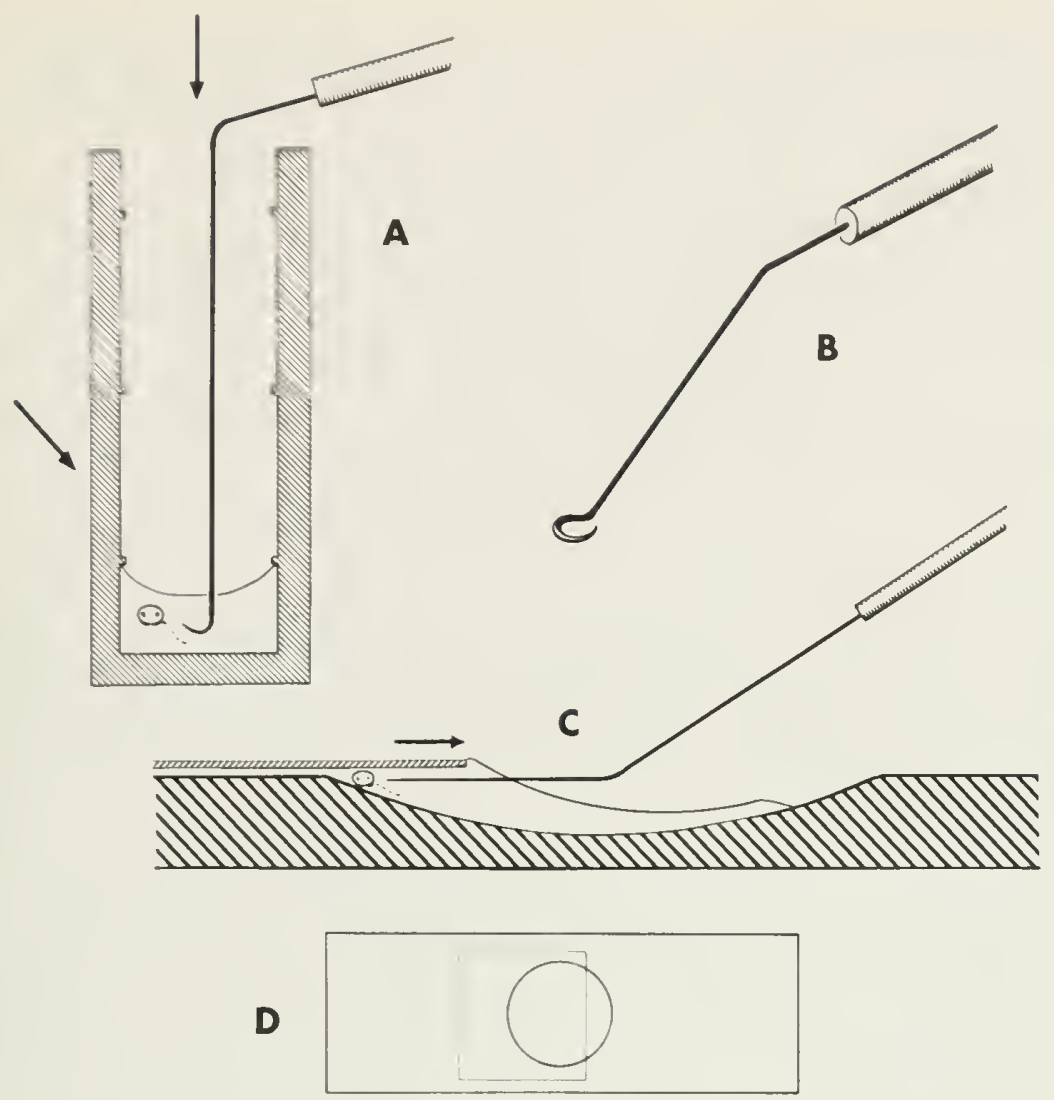

Fig. I A. Retrieval of specimens from a polyethylene microvial. Upper arrow indicates direction of observation through dissecting microscope, lower arrow, direction of incident illumination.

B. A wire microloop for transporting minute specimens.

C. Preparation of a glycerin temporary mount on a concavity slide (after Evans et al., 1961, fig. 105). Arrow indicates direction of coverslip motion.

D. Completed temporary mount on a concavity slide (after Evans et al., 1961, fig. 104).

required, as glycerin does not evaporate appreciably. Cork stoppers tend to shed fragments onto the surface of the glycerin; neoprene stoppers supplied with plastic genitalia vials are cleaner but more expensive (approximately three times the cost of microvials).

Microvials are stored dry in a larger glass vial containing the various data labels that accompany the collection. A microvial can also be stored on its side, mounted on an insect pin thrust through the cork. because hydrophobic polyethylene prevents glycerin from creeping along the wall. The glycerin drop remains immobile in the bottom of the vial, holding the specimens there until needed. 
The final step in preservation of the associated female and larvae is the transfer of the female from GAW to a drop of glycerin in a polyethylene microvial. The microvial can then be placed dry in the same larger vial containing larvae and labels.

\section{PRACTICAL CONSIDERATIONS}

For most rearing operations (sorting field collections, handling adults and larvac) a low-power, stereoscopic dissecting microscope with continuously variable (pancratic or zoom) magnification is rccommended. The lower extreme of the magnification range should be as low as $10 \mathrm{X}$. and rarely (including, for the experienced workcr, most generic determinations) will magnifications greater than $40 \mathrm{X}$ be required.

The entire opcration of rcaring mite larvae is time-consuming, and to carry out a large-scalc program in the field during extended collecting trips is inadvisable; three days' work on the rearing matcrial is required for each day to collect adults. Field rearing, however, may be necessary for rare mitcs or for species of particular interest. But the most efficient arrangement is to maintain both a field party collecting adults and a support staff rearing and harvesting in the laboratory.

Ficld collections receive an initial sorting (although they need not) and arc mailed to the laboratory (airmail if necessary) in capped vials in a sturdy, protective, mailing container. Mortality is low when mailing time is no more than 2 or 3 days, but larvac from females that were as long as 5 days in transit have been successfully reared. It is essential when packing mites for shipment to provide a high level of dissolved oxygen by filling the vials no more than half full of water (short, wide vials also improve the surface: volume ratio) and by drastically restricting the number of mites per vial. Only 10-15 medium-sized mites (c.g., Limnesia spp., Piona spp., or Arremurus spp.) travel successfully together. Even smaller numbers (2-5) per vial will be necessary with large species, such as some Hydrachna and Eylais. For cold-water species, it might be advisable to insulate the shipping container and possibly to provide some means to cool the contents in transit. Most adult mites, however, tolerate high tempcratures for some time, and we have successfully mailed and reared cold-water mites at ambient summer temperaturcs.

If the duration of the collecting trip is no more than a week, collcctions may be stockpiled in an ice chest $\left(5^{\circ} \mathrm{C} \pm\right.$ ) and sorted for laboratory rearing on return. Some oviposition may occur in the field, and larvac from these eggs cannot be positively associatcd with a specific female.

\section{Observation and Final Storage of Skeletal Preparations}

\section{EXOSKELETON OF ADULTS AND NYMPHS}

\section{Sorting and Clearing}

Adult mites preserved in GAW are casily cleared for microscopic examination. Initial sorting by an experienced worker may be carried out under a dissecting microscope without clearing. For critical study, species determination, and separation of similar or closely related genera, a cleared speci- 
men mounted on a slide should be exanined by transmitted light at 100400X. Acetic corrosive (André's fluid), described by Mitchell and Cook (1952), is satisfactory for clearing most adult water mites preserved in GAW: The other clearing agent also mentioned by those authors (ibid.). $10 \%$ potassium hydroxide $(\mathrm{KOH})$, should be used with the several families of heavily sclerotized mites having characteristic pigmention of the dorsal sclerite (c.g., Torrenticolidae, Aturidac, Axonopsidac, Mideidac, Midcopsidae. Krendowskijidac, and the genus Koenikea). Such patterns are obliterated by acetic corrosive but are unaffected by gentle KOH clearing.

The technique of Essig (1948) for clcaring alcohol-preserved specimens is satisfactory, but the process is tedious. Possibly the cnzymatic maceration described by Newell (1947) could also be valuable in reclaiming adult mites preserved in improper fluids.

\section{Dissection}

Specimens can be dissected with only a few, specialized instruments. Most appendages are easily removed by inserting a fine needle (e.g., no. 00 insect pin) at the base; only a small amount of pressure is needed to separate the appendage from its socket. A difficult dissection is the separation of dorsum from venter in specics lacking a sclerotized dorsal platc. Large specimens $(\geqslant 2 \mathrm{~mm}$ in diameter) can be dissected readily into dorsum and venter with a pair of fine. surgical scissors. Scissors cannot be used on mites less than $1 \mathrm{~mm}$ in diameter, although other workers have had success with sharpened needles or glass scalpels (pcrs. comm.). Separation of dorsum and venter is important primarily in large or heavily-sclerotized mites where the presence of one surface seriously impedes the transmission of light througl the surface being examined. Usually, in heavily-sclerotized species, a wellmarked line separates the dorsum and venter, and the insertion of needles at several points along this membranous zone will scparate the two halves of the body completely. In smaller, lightly-sclcrotized species, such interference is minimal, and these specimens can be successfully studied in temporary mounts without extensive dissection.

\section{Classical Slide Mounting}

The classical method of preparing specimens for observation and permanent storage (Mitchcll and Cook, 1952) consists of a double-coverslip slide mount containing a dissected specimen embedded in glycerin jelly, a medium of low refractive index. Although these mounts arc casy to cxamine initially and provide a high degree of permanence for muscum collections, they have several disadvantages. After 10-15 years, specimens preserved by the double-coverslip technique tend to accumulate an external deposit consisting of orange-brown droplets that often obscure structural details. A disadvantage common to all permanent mounts is that structures cannot be further manipulated or dissected. A related restriction is that the relative thickness of many such preparations precludes the free use of oil immersion and some "high-dry" objectives. A final and perhaps most compelling disadvantage of the permanent mount is the considerable amount of time required to prepare each specimen. 


\section{Fluid Storage}

Permanent prescrvation in glycerin eliminates the difficulties deseribed for permanent, double-coverslip slide mounts and has few serious disadvantages. Adult mites are cleared and then stored in $96 \%$ glycerin, either in groups in large vials or singly in polyethylene microvials ( $\sec$ p. 10). To examine the specimen, it is removed from the microvial, placed on a concavity slide in a drop of glyecrin, and treated as a temporary mount. The main disadvantages are the handling time required for each observation and the difficulty of maintaining numerous temporary mounts simultaneously during a taxonomic study. The second restriction may be eased by routine and consistent use of black-and-white photography during an investigation. Much sorting and gross inspection can be done with photographs, resorting to the specimens only for critical details.

Storage in fluid allows any of the standard dissections needed to examine discrete organs ( $v i z$. removal of dorsum, capitulum, palp, leg, or ejaculatory complex). Most parts can be stored together in the same drop of glycerin in a microvial; cach ean be retricved individually with the proper tools. Although the ejaculatory complex can be stored with other structures (see p. 16), because of its great transparency and small size it may be easicr to recover if stored separately in its own microvial.

To retrieve specimens, the microvial should be uneorked and placed vertically on the stage of a dissecting microscope. With practice, the container can be held in the fingers for this operation or placed in a rack or stand, holding it firmly under a strong sourec of light (Fig. 1A). Illumination is through the side or from below; translucent polyethylene walls disperse light, illuminating the interior of the vial so that even the smallest parts are visible. Smaller organs are worked up through the glycerin with a straight pin and then taken through the surface by simple adhesion to the side of the pin. Larger structures (legs, capitulum) can be removed with a minutenpin microloop similar to that described for transferring mite larvae (Fig. 1 B). The largest parts (dorsum, venter, wholc mite) are also retrieved with the loop or with a minuten pin hooked at the tip. Retricval of specimens can be facilitated if the upper part of the microvial is sliced off so that total height is about $1 \mathrm{~cm}$. A shorter vial is still satisfactory for permanent storage.

I advocate glycerin (96\%) for long-term storage of larvac and adults. The low volatility and high density of this inert fluid make it ideal to proteet minute chitinous specimens from chemical and mechanical damagc. The polyethylene microvial is also resistant to damage and should further proteet the material. Thus, the method seems to satisfy the requirements for indefinite muscum storage of important taxonomic materials (types, voucher specimens). Entomologists, of course, have stored genitalia preparations in glyecrin for some time with apparently satisfactory results (Bcirne, 1955, p. 69).

\section{Temporary Mounts}

A specimen stored in fluid can be transferred to a drop of glyecrin in a concavity slide and observed as a temporary mount. For examination at low 
power or with a high-dry objective of 1-2 mm working distance, no coverslip is required. If the surface of the glycerin is approximately flat, illumination and resolution will be sufficient for routine examination.

A temporary mounting techniquc allowing critical observation (Grandjean. 1949) is commonly used by acarologists to study terrestrial mites. The specimen is placed on a concavity slide near one edge of the depression. A squarc coverglass is laid over that edge of the depression so that glycerin is drawn under it by capillary action (Fig. Ic). The coverslip is slid farther across the depression, trapping the specimen beneath it, while a minuten pin inserted beneath the slip keeps the specimen in place near the edge of the depression. Glycerin is added when needed to prevent formation of an air bubble. The preparation is complete when the leading edge of the coverslip is about two-thirds the distance across the depression (Fig. 1D), with the specimen wedged between the coverslip and the sloping bottom near the edge (Fig. 1C). In this position, small structures can be oriented by slight movements of the coverslip. If the coverslip is later fixed in place on the slide with three or four drops of clear nail polish or wax, the preparation can be safely examined with an oil immersion objective.

\section{Semi-Permanent Mounts}

For a reference collection of identified material, slide-mounted specimens provide rapid and easy access and require a minimum of experience for examination. A collection of slides can be quickly accumulated by mounting adult mites in Hoyer's Medium (Wards Natural Science Establishment, Inc., Rochester. N.Y.). These slides are not permanent even though coverslips are sealed with an impervious ringing compound such as Murrayite (Fisher Scientific Co. Ltd., Montreal, Que.). But for short term (10-20 years) use, they are satisfactory. Additional coatings of the sealant after 1-5 years probably extend the useful life of the preparation.

A major problem with single-step mounting techniques is that they do not allow for orientation of dissected parts (Mitchell and Cook, 1952). If the mount is prepared in iwo stages, however, perfect placement of structures is possible. A large drop of Hoyer's medium (the exact size determined by experience) is placed on a slide. and in it are placed the dissected structures of the mite. These structures may be transferred from $70 \%$ ethanol, water, or GAW and should have been cleared before mounting. The parts are then arranged as described by Mitchell and Cook (1952), excess mountant is removed by drawing it across the surface of the slide with a needle, and the preparation is set aside under a dust cover to dry. In dry weather, after a day or two at room temperature, the mounts will have hardened and the specimens are covered by a thin film of the medium. Occasionally air bubbles develop under sclerites and within appendages, and the value of such mounts is reduced.

Next, a second drop of Hoyer's medium is placed on the dissected parts (now glued to the slide), and a coverslip is lowered gently onto the preparation at once. Minimal pressure is applied during the final seating of the coverslip because fresh medium rapidly softens the hardened film, and 
parts can still be displaced. The slide is then dried (1-2 weeks at room temperature or $3-5$ days at $40^{\circ} \mathrm{C}$ ), and the coverslip is ringed with Murrayite. Water-soluble ringing compounds should be avoided, because they do not protect the slide from further desiccation or excessive hydration.

It is important that the amount of hardened medium covering the specimen after the first operation be small; sclerites must appear as structures raised above the surface of the slide, with the medium only covering them. Then, when the final drop of medium is appliecl, the coverslip can settle down to the surface of the specimen. The thickness of the resulting mount is comparable or superior to those prepared by the double-coverslip technique.

\section{Permanent Mounts}

A good method (Newell, 1947) of preparing permanent mounts of dissected mites utilizes Hyrax (Van Waters and Rogers, Inc., Seattlc, Washington). This medium is permanent, has a resinous base, does not yellow appreciably with age (I. M. Newell, pers. comm.), and has a favourable refractive index (1.65) for mite exoskeletal parts. Hyrax can be employed in a tivo-step mounting process as described for Hoycr's. Dissected parts are first dehydrated (70\% ethanol, 95\% cthanol, bechwood creosote) and transferred to xylene before being placed in a drop of Hyrax on the slide. Hardening time for each stage is longer than with Hoyer's but can be decreased by drying at $40^{\circ} \mathrm{C}$.

Hyrax may be replaced in permanent mounts by Canada balsam or other resinous medium. Balsam, however, becomes yellow with age and has an unfavourable refractive index for mite chitin (Mitchell and Cook, 1952); but, with the availability of phase and interference contrast microscopes at present, balsam mounts can be studied casily.

\section{EJACULATORY COMPLEX}

One organ of the adult mitc is unsuited to preservation as a fixed mount. The male ejaculatory complex (EC), because of its small size and intricate, three-dimensional structure (Barr, 1972), is necessarily stored and studied in fluid. Skeletal preparations of the EC are readily prepared from mites preserved in GAW. Soft-bodied species are punctured in the posterior or dorsal body wall, and the EC is teased free with a hooked minuten pin. With hard-bodied mites one must first separate the dorsum from the venter (or remove the caudum for Arrenurus spp.) before the EC skeleton can be extracted.

The detached EC is transferred in a drop of glycerin to a white porcelain, concavity plate ( 16 holes), and subsequent steps are carricd out in the various depressions of this plate. The preparation is stained in Eosin-Y in glycerin-alcohol (about 2 minutes) to make it easier to keep in vicw during the next, or clearing, step in Nesbitt's fluid (5-15 minutes). Clearing must be monitored closely for, if left overlong, the specimen may become too transparent to ketect and be lost. After clearing has removed all soft tissues, the preparation is washed in distilled water, restained (Eosin-Y in glycerin-alcohol), passed through $75 \%$ ethanol, $95 \%$ ethanol, bechwood creosote, and xylenc (2 minutes each), and eventually transferrect to $\mathrm{VH}$ 
viscosity immersion oil (R. P. Cargille Laboratories. Inc., Cedar Grove, N.J.). The specimen is handled each time under the dissecting microscopc with a minuten-pin microloop (Fig. I B) and must be transferred rapidly to the next fluid (especially after alcohol steps) to prevent drying. Once in immersion oil, the EC can be transferred with a straight mimuten (in holder) to which it will adhere when brought to the surface. Restaining the specimen aids somewhat in observation but is suggested primarily to make it easy to locate after storage in a drop of oil at the bottom of the microvial. Handling the EC skeleton of minute species is simplified if the entire male mite is processed as described above, and the EC is removed only after the specimen is in immersion oil.

The sheletal preparation is studied in a drop of VH viscosity immersion oil on a shallow, glass depression-slide. The temporary mount may be examined without a coverslip. A small mat of cellulose fibers from a facial tissue submerged in the oil forms a suitable, irregular surface on which to place the specimen. The cellulose fibers support and hold the EC, and the high viscosity of the immersion oil ensures that the preparation remains in any orientation at least for several days, sufficient time for observation, drawing, or photography. For critical examination a temporary mount with coverslip (see p. 14) is used, and VH viscosity immersion oil is substituted for glycerin. The ability to orient the specimen by pressure on the coverslip is particularly valuable for EC mounts.

The skeletal preparation may be stored permanently in a drop of immersion oil at the bottom of a polyethylene microvial (see p. 10). The vial is corked and must be stored upright, as the oil will slowly flow along the side of a horizontal vial. VH viscosity immersion oil is advertised to be nondrying by the inanufacturer, and I have noted no evaporation in preparations stored for 5 years.

\section{LARVAE}

The small size of larval specimens (100-500 $\mu \mathrm{m}$ in length) creates difficulties of storage and observation. Preservation in $70 \%$ ethanol plus glycerin and subsequent storage in a drop of glycerin has been described. Specimens stored in glycerin appear to remain in good condition indefinitely.

Perhaps the most satisfactory method for examining larvae is in fresh Hoyer's mounts (see Semi-permanent Mounts, p. 15) prepared at the time of harvesting. As many as six siblings can be mounted under the same coverslip. Larvae are initially opaque, but after drying in an oven at $40^{\circ} \mathrm{C}$ for 3 days to a week, they become thoroughly cleared. The coverslip must be ringed with Murrayite after drying, however.

I have no evidence that Hoyer's mounts continue to shrink with time, eventually pressing the dorsum and venter of the larva closely torether, even in slides 6 years old. If dorso-ventral compression were to occur in poorly sealed mounts, a working knowledge of larval anatomy should prevent confusion. Nor have any of the specimens stored for 6 years become overcleared by continuing action of the medium. 
Semi-permanent mounts, however, cannot be manipulated or turned to observe different aspects of the specimen, nor can specimens readily be prepared for viewing with the scanning electron microscope. Specimens in Hoyer's can be freed by cracking the coverslip and submerging the entire slide in a small petri dish of water at $40^{\circ} \mathrm{C}$ for an hour (longer if necessary). The coverslip can then be floated away and the larvac removed.

Larvac prescrved in glycerin can be mounted directly in Hoyer's medium with results almost equal to those for a living specimen. Specimens, first cleared in lactic acid (or acetic corrosive) and preserved in glycerin, can also be examined as temporary mounts and rotated, turned, and manipulated to view structures from different angles. Dissection by teasing, or by crushing beneath the coverslip as suggested by Prasad and Cook (1972, p. 6), can aid in the obscrvation of individual structures.

Dried larvac may be the only material availab!e because of accidents in processing, becausc of drying specimens for the scanning electron microscope, or because larvae wcre obtained from dried insects in muscum or other collections. These specimens can be reclaimed for transmitted light microscopy by softening in lactic acid at $40^{\circ} \mathrm{C}$ for 24 hours. Larvac can, in fact, be preserved indefinitely in lactic acid, although I prefer to keep all material in glycerin to avoid confusion conccrning the preservative used for a given specimen.

Larvac killed by gentle heating and left to macerate in water for several days expand slightly (Prasad and Cook, 1972, p. 6), with the result that setal patterns may be seen more clearly. This procedure is probably not necessary for routine preparations after basic morphology is known.

\section{OPTICAL SYSTEMS}

A dissecting microscope and reflected-light illumination suffice to identify most genera of adult water mites and species of the genus Arrenurus. Study of most adult mites for detailed morphology requires preparation of the cleared exoskeleton in a temporary or permanent slide mount and observation at magnifications of $100-1000 \mathrm{X}$ by bright-ficld microscopy. In an embedding medium of low $(<1.5)$ refractive index, most adult structures are too heavily sclerotized for observation with phase or interference contrast systems.

The male EC skelcton, however, requires the highest levels of magnification, and observation is enhanced by increased contrast. Phase contrast microscopy cannot be used successfully on this material as the excessive multiplication of interference fringes obscures detail. But interference contrast (Normarski phase) microscopy improves the image. The thickness and moderate sclerotization of the specimens do not affect resolution, and the detailed structurc of membranes, lightly-sclerotized surfaces, and apical setae are more casily secn than with phase or bright-ficld. Internal structure is also somewhat clcarcr.

Cleared larvae are transparent and ncarly invisible with ordinary brightfield illumination. Phase contrast is gencrally satisfactory except in heavilysclerotized areas of the gnathosoma and in lightly-sclerotized structures or 
membranous areas. The technique is effective for determining size, shape, and lration of setae and of major body sclerites. Interference contrast is equally as effective for setal size, shape, and position and for major sclerites. In addition, somewhat greater detail is visible in heavily-sclerotized areas, in areas where the setae are dense, as in the palpal tarsus, and in lightlysclerotized structures.

\section{Studies of Internal Anatomy}

Apparcntly techniques for investigating the internal morphology of larvac have not yet been tested. Ultra-thin sections cut from resin-embedded specimens with an ultra-microtonc would probably produce informative results.

Adult specimens for gross dissection can bc prepared by cellulose nitrate infiltration and then affixed to a paraffin surface (Mitchell, 1964). Qualitative information on shape, sizc, and location of muscle bundlcs of the ejaculatory complex can be obtained by examination of the organ, rcmoved before clearing from mites prescrved in GAW. Muscle bundles are semitransparent and only loosely attached to the chitinous framework, so superficial layers can be rcmoved to examine deeper muscle groups.

Serial sections of whole mites require specimens infiltrated with cellulose nitrate and embedded in Paraplast (Mitchell, 1964). Sections are cut at $5-10 \mu \mathrm{m}$ in longitudinal (sagittal), transverse, and frontal planes. Ribbons are affixed to slides with Mayer's albumin, stained with Mallory's triple stain (Gray, 1964. pp. 111-112), and mounted in Canada balsam.

Mallory's stain tends to fade with time, although less so in acid balsam mounts (Gray, 1964), but for initial morphological studies of arthropods it is invaluable because of the colour distinction given to different tissues. Nuclei stain red. connective tissues blue, glandular tissues blue or purple, muscles red, gonadai tissues red or magenta, and secretions are often blue. The components of the exoskeleton are particularly well differentiated; unsclerotized chitin stains bright blue (hypostracum or endocuticle), lightly sclerotized exoskeleton stains red (ectostracum or exocuticle), and heavily sclerotized areas remain yellow (i.e., unstained). Once various organs and tissues have becn identified subsequent preparations should be stained with the permanent dye, iron hematoxylin.

\section{Scanning Electron Microscopy}

\section{APPLICATIONS}

The scanning elcctron microscopc (SEM) has proven useful for the study of external features of water mites. For adults it has provided micrographs of the entire ventral surface showing sclerites and setae. SEM micrographs yield new information on sctae and on structure of small or difficult-toobserve surfacc featurcs of the body such as acctabula (genital suckers), eupathidia of the papal tarsus, various glandularia, pores, tip of the capitu. lum, and cyc capsules. Particularly for larvac, scanning electron microscopy is invaluablc. Much of the larval observation done with a light microscope is at the limits of magnification and resolution of conventional optical sys- 
tems; additional clarification of palpal setation, setal types, sense organs, the anal plate, and other exoskeletal structures is possible only with the SEM.

\section{DESICCATION}

To make a satisfactory specimen, the mite must be dried, fixed to an aluminum specimen stub, and vacuum coated with a thin layer of metal or other conductor (c.g., carbon) so that every point on the surface is grounded. With many adult mites simple air drying suffices. Specimens are removed from the preservative (glyecrin, GAW, or a histological fixative) and transferred through several (2-6, as needed) changes of $70 \%$ ethanol to wash out glyecrin or other non-volatile reagents. Fragile specimens may be transferred to absolute ethanol and then to xylene to render exoskeletal structures more rigid and to reduce collapse upon desiccation. After removal from xylene, air drying is rapid. Weakly-sclerotized species of certain genera (e.g., Atractides, Eylais, Unionicola, and Hygrobates) and all nymphs benefit by frecze-drying. Acrial larvae are fragile and can be desiccated satisfactorily only by freeze-drying. But aquatic larvae are more robust and can be treated much the same as adults; air-drying directly from xylene is advisable for additional rigidity. Although the air-drying technique for aquatic larvac is rapid, it usually obscures integumental areas, which collapse inward, leaving the heavily-sclerotized plates outermost.

For frecze-drying, specimens should be washed thoroughly in $70 \%$ ethanol (at $40^{\circ} \mathrm{C}$, six changes in 24 hours) to be certain that all glycerin is removed. The material is then frozen in a gentle, two-stage method. Liquid freon is prepared by spraying the gas from a pressurized tin into a small metal vial floating on the surface of liquid nitrogen. The freon freezes at the botton of the vial, and a quarter-inch deposit of frozen freon can be built up quickly. The container is then removed and placed on the surface of a laboratory bench at room temperature. Within a few minutes the freon melts but will not cvaporate in less than 20-30 minutes. Mite specimens are isolated in small cups of aluminum foil. Excess alcohol is drawn off so that specimens are covered by only a thin film. The aluminum cup is then floated on the surface of the liquid freon, which freezes it almost instantaneously, and after a minute or two the cup is transferred to the surface of liquid nitrogen. Frozen specimens may then be stored in liquid nitrogen or in a freczer, or they may be transferred directly to the pre-cooled stage of the freeze-dryer. After freeze-drying. no particular precautions necd be taken with specimens, and they ean be stored in the laboratory under atmospheric conditions.

\section{MOUNT1NG AND COATING}

Affixing dried specimens to stubs has been one of the most diffieult steps in the preparation of SEM material. Any gluing agent that dries too rapidly is uscless because the light, small specimens camnot be transferred to the drop of glue before a thin, dried film forms over the surface of the drop, preventing the speeimen from being pushed into it. Consequently, the otherwise favourable silver dag (a dense suspension of silver particles in a quick(lrying earrier fluid) cannot be used as a gluing agent for mites. The best 
alternative has been epoxy resin cement applied to the stub in small quantitics. each spot no more than $10 \%$ of the total volume of the body of the animal to be affixed. Larger quantities tend to migrate up the sides of the specimen, coating it and obscuring most surfacc detail. Adult mitcs can bc transferred to the dab of cement with cxtreme care by a pair of fine watchmaker's forceps. But dried larvae are transferred morc casily bccause they tend to adhere to the tip of a dry minuten pin by clectrostatic attraction. Once on the liquid resin, the specimens should be slightly pushed into it to ensurc firm adhesion.

The hardened resin is totally non-conducting, and so grounding of the surface of the specimen must be thorough. With larger specimens, grounding can be accomplished by painting silver dag (Achcson Colloids Ltd., Brantford, Ont.) around the margin of the specimcn to ensure a conductive path from the body surface to the aluminum of the stub. Dag, however, cannot be used for larvae; even the slow-drying variety forms a surface skin too rapidly to allow a drop to be touched to the edge of the larva and drawn out across the stub.

A second method of cnsuring good grounding is to vacuum-coat the specimen with a particularly hcavy metallic layer (e.g., 400-500 $\AA$ ) and, if necessary, to coat a second timc beforc observation. Excessive coating does not obscure detail on most structures of interest in water mite morphology. For all mites obscrved herc, pure gold has been the most satisfactory coating agent.

At high magnifications, debris and dirt particles on specimens, particularly those that have been freeze-dried, occasionally impede observation and certainly decrease the quality of micrographs. Specimens can be cleaned and most particulate matter removed by sonication as described by Shcar and Levi (1970).

\section{LIMITATIONS}

Scanning electron microscopy is not a completely satisfactory method for the study of the external morphology of water mites. Many well-marked sclerites that are easily scen by transmitted light are difficult to observe with scanning electron microscopy because they are partially sunken beneath the surface of the integument. This is also truc, of course, for apodemes, ridges, and any other internal structure. Legs and other long, thin appendages projecting from the body are difficult to observe because they cannot be thoroughly grounded; they often charge in the presence of the electron beam and glow too brightly. When using the scanning clectron microscope to prepare taxonomic illustrations, it is difficult to oricnt specimens so that legs and other appendages are well displayed. Moreover, in micrographs of the entire ventral surface, the smaller coxal setae are difficult to distinguish.

\section{Illustrations}

\section{LINE DRAWINGS}

Black-and-white line drawings are still the most versatilc illustration for all phases of water mitc study, especially for taxonomic description. Methods 
size, was first used for water mite larvae by Barr (1968). Each larval leg is represented by a standardized diagram marked with symbols to indicate the position of the setal bases. Individual setae that are diagnostieally important because of size or strueture are illustrated separately. Although the value of the setal diagram is only auxiliary in diagnosis, it facilitates interspecifie comparison of individual setal positions and of overall setal patterns as noted by Evans (1963) for Mesostigmata. Suel diagrams also provide suitable data for quantitative analysis. Beeause distortion is involved in making each segment fit a standard shape and size, setal diagrams should always be acempanied by an outline drawing of the leg segments marked to indieate the true position of setal bases.

\section{PHOTONICROGRAPHY}

Photomierography has been important as a method of illustrating water mites. Many' of Lundblad's publications (e.g., 1941. 1962) eontain photomierographs of entire ventral and dorsal views as well as isolated views of palp, genital area, and specific leg segments. His photographs were usually supplemented by detailed line drawings of struetures of particular interest. Certain water mite struetures, e.g., palps, flat dorsal plates, pigmentation pattern in dorsal plates, and often the external genitalia, are more rapidly and better illustrated by photomicrography than by line drawings. By photographing the specimen at low magnification with inereased enlargement of the negative, onc can take advantage of a greater depth of field than is available at high magnification. A good photograph is a more objective record of shape and relative sizes than many taxonomie drawings.

In studying a specimen or series of specimens, a reeord set of photomierographs is valuable. Photographs ean be sorted and examined more easily and effieiently than slides. especially temporary mounts, which need only be re-examined in the final stages of the investigation rather than throughout. Photomicrographs can also serve as the basis for line illustrations and for certain quantitative analyses. Moreover, photographs can be used to illustrate variation of shape in a particular strueture more expediently than a series of line drawings. Possibly improved seanning electron micrographs will eventually eliminate some of the disadvantages (shallow depth of field, low contrast) of standard photomicrographs. 


\section{Acknowledgments}

Ian M. Smith developed several techniques described here and has been a continuing source of helpful ideas, practical assistance, and stimulating discussion. Conversations with Drs. David R. Cook, G. Owen Evans, Carmine A. Lanciani, Rodger D. Mitchell, and Vikram Prasad provided many valuable suggestions. T. Gledhill and K. H. Hyatt provided information on phreaticolous collecting and storage methods, respectively.

During the 10-ycar period that these methods have been developed, financial support came from a number of sources: Cornell University, the National Research Council (Canada), Allied Chemical Company, Ontario Department of University Affairs (Grant-in-Aid of Research), and the Canadian National Sportsmen's Show (Conscrvation grant). Some collections were made during RoM field trips supported by grants to Dr. G. B. Wiggins from the National Science Foundation (grant GB4021), the Canadian National Sportsmen's Show, the Fishcries Research Board of Canada, and the National Research Council of Canada (grant A5707).

Acknowledgment is made for use of the scanning electron microscope of the Laboratory of Analytical Systematics, Univcrsity of Toronto, in the Royal Ontario Museum. Mrs. C. Johnston provided valuable technical assistance in use of the SEM, and A. Troiki, Laboratory of Analytical Systematics, developed the freeze-drying method described here. Mrs. P. B. Buckley carried out scveral thousand larval rearings, and Mrs. J. Allan typed two drafts of the manuscript. The cover illustration of Frontipoda americana Marshall was donc by A. Odum. 


\section{Appendix: Formulac for Reagents}

1. Acetic Corrosive (André's Fluid) (Mitchell and Cook, 1952)

$\begin{array}{ll}\text { acetic acid (glacial) } & 50 \mathrm{ml} \\ \text { chloral hydrate } & 50 \mathrm{~g} \\ \text { distilled water } & 50 \mathrm{ml}\end{array}$

2. Brasil’s Fluid (calculated from Baker, 1958)

$\begin{array}{lc}80 \% \text { ethanol } & 150 \mathrm{ml} \\ \text { picric acid } & 1 \mathrm{~g} \\ \text { formalin }(37 \%) & 70 \mathrm{ml} \\ \text { acetic acid (glacial) } & 15 \mathrm{ml}\end{array}$

3. Eosin-Y in Glycerin-Alcohol (Barr)

saturated solution of

Eosin- $Y$ in $95^{\circ} \mathrm{c}$ ethanol $\quad 10 \mathrm{ml}$

glycerin $(96 \%) \quad 10 \mathrm{ml}$

4. GAW' (modified Koenike's fluid)

$\begin{array}{ll}\text { acetic acid (glacial) } & 100 \mathrm{ml} \\ \text { glycerin }(96 \%) & 500 \mathrm{ml} \\ \text { distilled water } & 400 \mathrm{ml}\end{array}$

5. Modified Carnoy's Fluid (De Giusti and Ezman, 1955)

$\begin{array}{ll}\text { isopropyl alcohol (abs.) } & 60 \mathrm{ml} \\ \text { chloroform } & 30 \mathrm{ml} \\ \text { formic acid }(90 \%) & 10 \mathrm{ml}\end{array}$

6. Nesbitt's fluid (Evans et al., 1961)

$\begin{array}{lc}\text { chloral hydrate } & 40 \mathrm{~g} \\ \text { distilled water } & 25 \mathrm{ml} \\ \text { hydrochloric acid (1N) } & 2.5 \mathrm{ml}\end{array}$




\section{Literature Cited}

BAKER, W, AND G. W. WHARTON

1952 An introduction to acarology. New York, Macmillan. 465 pp.

BAKER, J. R.

1958 Principles of biological microtechnique. London, Methuen. 357 pp.

BARR, D.

1968 Limmesia (Limnesiella) marshallae, description of larva. Pilot Register of Zoology, Card No. 26.

1972 The ejaculatory complex in water mites (Acari: Parasitengona): morphology and potential value for systematics. Life Sci. Contr., R. Ont. Mus., no. 81, pp. 1-87.

BEIRNE, B. P. (compiler)

1955 Collecting, preparing and preserving insects. Sci. Serv., Entom. Div., Can. Dept. Agric., publ. 932, pp. 1-133.

CLIFFORD, H. F.

1972 A year's study of the drifting organisms in a brown-water stream of Alberta, Canada. Can. J. Zool., vol. 50, no. 7, pp. 975-983.

COOK, D. R.

1963 Studies on the phreaticolous water mites of North America: new or unreported genera of Axonopsidae. Amer. Midl. Nat., vol. 70, pp. $110-125$.

1968 Water mites of the genus Stygomomonia in North America (Acarina, Momoniidae). Proc. Ent. Soc. Wash., vol. 70, pp. 210-224.

COOK, D. R. AND R. D. MITCHELL

1952 Notes on collecting water-mites. Turtox News, vol. 30, no. 8,4 pp.

CROWELL, R. M.

1960 The taxonomy, distribution and developmental stages of Ohio water mites. Bull. Ohio Biol. Surv., N. Ser., vol. 1, no. 2, pp. 1-77.

DE GIUSTI, D. L. AND L. EZMAN

1955 Two methods for serial sectioning of arthropods and insects. Trans. Amer. Micros. Soc., vol. 74, pp. 197-201.

ESSIG, E. O.

1948 Mounting aphids and other small insects on microscope slides. Pacific Ent., vol. 24, pp. 9-22.

EVANS, G. O.

1963 Observations on the chaetotaxy of the legs in the free-living Gamasina (Acari: Mesostigmata). Bull. Brit. Mus. (Nat. Hist.), Zool., vol. 10, no. 5, pp. 277-303.

EVANS, G. O., J. G. SHEALS AND D. MACFARI.ANE

196 I Terrestrial Acari of the British Isles. Vol. 1. London, British Museum (Natural History). 219 pp.

GRANDJEAN, F.

1935 Observations sur les acariens (1ère série). Bull. Mus. Nat. Hist. Nat., Paris, 2" ser., vol. 7, pp. 119-126. 
GRANDJEAN, F.

1949 Observation et conservation des tres petits Arthropodes. Bull. Mus. Nat. Hist. Natur., Paris, 2"ser., vol. 21, pp. 363-370.

GRAY, P.

1964 Handbook of basic microtechnique. New York, McGraw-Hill. $302 \mathrm{pp}$.

KR+NTZ, G. W.

1970 A manual of acarology. Corvallis, O.S.U. Book Stores, Inc. 335 pp.

LANCLANI, C. A.

1970 New species of Eylais (Acari: Eylaidae) parasitic on aquatic Coleoptera. Trans. Amer. Micros. Soc., vol. 89, pp. 169-188.

\section{LUNDBLAD, $O$.}

1941 Dic Hydracarinenfauna Sudbrasiliens und Paraguays. Erster Teil. Sirensk. Vetensk.-akad. Handling., Stockholn. (ser. 3), vol. 19, no. 7,pp. 1-183.

1962 Die Hydracarinen Schwedens. II. Arkiv För Zoologi: Svenska Vetensk.-akad., ser. 2, vol. 14, no. 1, pp. 1-635.

MITCHELL, R. D.

1960 The evolution of thermiphilous water mites. Evolution, vol. 14, pp. $361-377$.

1964 The anatomy of an adult chigger mite Blankaartia acuscutellaris (Walch). J. Morph., vol. 114, pp. 373-391

MITCHELL, R. D. AND D. R. COOK

1952 The preservation and mounting of water-mites. Turtox News, vol. 30, no. 9,4 pp.

MOTAS, C.

1962 Procédé des ondages phreatiques - Division du domaine souterrain Classification ecologique des animaux Souterrains - Le psammon. Acta Mus. Maced Sci. Nat., vol. 8, no. 7, pp. 135-173.

NEWELL, I. M.

1947 A systematic and ecological study of the Halacaridae of eastern North America. Bull. Bingham Oceanographic Collection, vol. 10, art. 3, pp. 1-232.

1959 Acari. In Edmondson, W. T. ed., Fresh-water biology. 2nd ed. New York, Wiley.pp. 1080-1116.

NEWELL, 1. M. AND R. E. RYCKMAN

1966 Species of Pimeliaphilus (Acari, Pterygosomidae) attacking insects, with particular reference to the species parasitizing Triatominae (Hemiptera, Reduviidae). Hilgardia, vol. 37, pp. 403-436.

OLDROYD, $\mathrm{H}$.

1970 Collecting, preserving and studying insects. London, Hutchinson. $336 \mathrm{pp}$.

PENNAK, R. W.

1953 Fresh-water invertebrates of the United States. New York, Ronald Press. 769 pp. 
PRASAD, V. AND D. R. COOK

1972 The taxonony of water mite larvae. Mem. Am. Ent. Inst., no. 18, pp. 1-326.

PIECZYNSKI, E.

1962 Notes on the use of light traps for water mites (Hydracarina). Bull. Acad. Pol. Sci., Cl. 11, vol. 10, no. 10, pp. 421-424.

1965 Effect of the size of traps and their exposure time on the catches of aquatic invertebrates, chiefly water mites (Hydracarina). Bull. Acad. Pol. Sci., Cl. 11, vol. 13, no. 10, pp. 577-581.

SHEAR, W. A. AND H. W. LEVI

1970 Cleaning museum specimens of spiders and myriapods with ultrasonics. Bull. Brit. Arach. Soc., vol. 1, p. 117.

VIETS, $\mathrm{K}$.

1936 Wassermilben oder Hydracarina (Hydrachnellae und Halacaridae). Die Tierwelt Deutschlands, vol. 31-32, pp. 1-574.

WOODRING, J. P. AND E. F. COOK

1962 The internal anatomy, reproductive physiology, and molting process of Ceratozetes cisalpinus, Ann. Ent. Soc. Amer., vol. 55, pp. 164-181. 


\section{LIERARY}

ROYAL CIVTARIO MUSEUNA 
